\title{
Why Islamic Banks Tend to Avoid Participatory Financing? A Demand, Regulation, and Uncertainty Framework
}

\author{
Muhammad Nouman ${ }^{1}$, Karim Ullah ${ }^{2}$, Saleem Gul ${ }^{3}$
}

\begin{abstract}
Participatory financing arrangements including Musharakah and Mudarabah are the essence of Islamic banking and represent the true spirit of Islamic banking and finance. Therefore, Islamic banks are expected to allow and promote participatory financing. In practice, Islamic banks adopt participatory financing arrangements for the scheme of deposits. However,they do not adopt participatory financing on the assets side due to several constraints. By far, the non-participatory financing arrangements, particularly Murabahah and Ijarah, are the most dominant modes of financing around the globe. Many authors have provided different explanations for the tendency of Islamic banks to avoid participatory financing. However, literature is divergent and the typology of the constraints to participatory financing is missing. Therefore, there is no unified understanding of the constraints to participatory financing. The present study employs insights form the extant literature using a systematic literature review and synthesizes a coherent participatory financing constraints framework using the thematic synthesis method to name and make sense of what makes participatory financing a less attractive option for Islamic banks. This study adds to the Islamic banking and finance literature by synthesizing the divergent literature, and conceptualizing a participatory financing constraints framework which can be used as a dependable framework for assessment in any related case study and policy implications. Moreover, it demonstrates an application of systematic review in Islamic banking research.
\end{abstract}

Keywords: Constraints, Participatory financing, Mudarabah, Musharakah, Islamic banking, Islamic finance, Systematic literature review.

\section{Introduction}

Islamic banking is a rapidly growing phenomenon particularly in the Muslim countries and the leading world financial hubs (Ahmad, 2000; Farooq, 2007; Iqbal,

1 PhD Scholar, Institute of Management Sciences, Peshawar.Email:mnouman@aup.edu.pk

2 Assistant Professor, Institute of Management Sciences, Peshawar. Email: karim.Ullah@imsciences.edu.pk

3 Assistant Professor, Institute of Management Sciences, Peshawar. Email: s.gul@imsciences.edu.pk

\begin{tabular}{lll} 
ARTICLE HISTORY & & \\
25 Oct, 2017 Submission Received & 27 Nov, 2017 & First Review \\
\hline 19 Dec, 2017 Revised Version Received & 6 Feb, 2018 & Second Review \\
\hline 21 Feb, 2018 Revised Version Received & 10 Mar, 2018 & Accepted
\end{tabular}


1997; Zaher \& Hassan, 2001). From an obscure financial experiment, Islamic banking clearly has transformed into a major factor in global finance (Khan, 2010). The worldwide capital of Islamic banks grew from US\$200 billion in 2000 to around US $\$ 3$ trillion by 2016, with this figure expected to reach $\$ 4$ trillion by the early 2020 s (World Finance, 2018). The growth of Islamic banking is a result of structural and macro-economic reforms in the financial systems worldwide, global integration of financial markets, privatization, the liberalization of capital movements and the introduction of new and innovative Islamic products (Iqbal, 1997; Zaher \& Hassan, 2001).

Despite the impressive growth of Islamic banking, a complete Islamic financial system is still nascent (Zaher \& Hassan, 2001). Many issues and challenges related to the different aspects of the Islamic financial system need to be addressed yet. One of the most dominant issues currently faced by Islamic banks is the overwhelming use of debt-like non-participatory instruments in their overall financing operations. Participatory financing (including Musharakah and Mudarabah financing) is the essence of Islamic banking. Therefore Islamic banks are supposed to allow and promote participatory financing. However, in practice they do not adopt them as the main financing schemes. By far the non-participatory arrangements particularly Murabahah and Ijarah are the most dominant modes of financing around the globe.

The extant literature indicates that the strong and consistent tendency of Islamic financial institutions to rely on non-participatory financing results from necessity, not from preference (Aggarwal \& Yousef, 2000; Bacha, 1995; Karim, 2002). Musharakah and Mudarabah have serious practical problems (Sumarti, Fitriyani, \& Damayanti, 2014). To avoid these problems Islamic financial institutions rely mainly on non-participatory modes of financing (Nouman \& Ullah, 2014).

Many authors have provided different explanations for the less utilization of participatory financing. However, the extant literature is divergent, with diverse studies focused on different dimensions of the issue. Due to the divergence in the literature there is no unified understanding of the constraints to participatory financing. Though Nouman and Ullah (2014) have attempted to integrate the extant literature. However, the typology of constraints remains missing. Therefore, this research strongly believes that it will be really useful and interesting to develop a coherent typology of the constraints identified by various scientific research efforts in the discipline.

This paper aims to extend the study of Nouman and Ullah (2014) and produce a coherent framework of the constraints to participatory financing. For this purpose, the present study employs insights form the extant literature using a systematic review and provides academia, practitioners, and policy makers with a coherent framework to name and make sense of what is making participatory financing a less attractive 
option for Islamic banks. The proposed framework provides grounds for creative reframing of the participatory financing arrangements, policy implications, and design of the control mechanisms for promoting participatory financing in Islamic banking.

The rest of the paper proceeds as follows: section 2 provides an overview of the theory and practices of Islamic banking, section 3 elaborates the review methodology employed in this study, section 4 presents the analysis of the literature, a coherent constraints framework has been developed in Section 5, and section 6 concludes the paper.

\section{Partici patory Financing in the Theory and Practice of Islamic Banking}

Participation and risk sharing, commonly known as the profit and loss sharing, is the essence of the design of Islamic financial products (Aggarwal \& Yousef, 2000; Ariff, 1988; Hearn, Piesse, \& Strange, 2012). A participatory financing arrangement allows the bank to earn profit on invested capital if the bank is willing to tolerate loss in case of the project failure (Aggarwal \& Yousef, 2000; Bacha, 1997). Moreover, the allocation of risk and reward to each partner, and the distribution of responsibilities among them are defined in the contract, which are enforced by the social values and the ethical standards set in the Shari'ah (Hearn et al., 2012).

The modes of participatory financing include Mudarabah and Musharakah. A Mudarabah arrangement entails partnership between investor(s) (Rabb Al-Mal) and entrepreneur(s) (Mudarib). Where an investor contributes capital while the entrepreneur employs effort and exercises complete control over the business (Abdouli, 1991; Aggarwal \& Yousef, 2000). Profits are divided according to a pre-agreed ratio, while in the event of a loss the losses are exclusively borne by the investor. Whereas, the entrepreneur loses compensation for his efforts (Bacha, 1997; ElGindi, Said, \& Salevurakis, 2009). Mudarabah is more akin to a limited liability partnership (Aggarwal $\&$ Yousef, 2000) and is further classified into restricted and unrestricted Mudarabah (Hearn et al., 2012). In case of the unrestricted Mudarabah, the agreement does not specify the place of business, its period, service or industry, the specific line of business, and customers or suppliers to be dealt with. On the other hand, the restricted Mudarabah has restriction on any of the above mentioned terms (Chapra, 1985, p. 247).

On the other hand, Musharakah is a type of partnership where all partners jointly contribute capital and manage the business venture (Abdouli, 1991; ElGindi et al., 2009). Profits are shared based on a pre-negotiated ratio, while losses are borne in proportion to the capital contributions by the partners (Aggarwal \& Yousef, 2000; Hearn et al., 2012; Kayed, 2012; Yousefi, McCormick, \& Abizadeh, 1995). Musharakah 
contracts are considered optimal in the development of Islamic private equity and venture capital markets, which require capital provision with some control and influence over their management (Al-Suwailem, 1998; Hearn et al., 2012; Khan \& BenDjilali, 2003).

The non-participatory modes on the contrary do not involve profit and loss sharing and an entrepreneur must pay a usually predetermined return. These modes include Ijarah (lease), Murabahah ('mark-up' or cost plus sale), Bai Muajjal (deferred payment), Istisna' (commission to manufacture), Salam (differed delivery), Qard Al Hasana (charity loan) and Jo'alah (service fee) (El-Komi \& Croson, 2013; Khan, 2010).

\subsection{Partici patory financing in the theory of Islamic banking}

Participatory financing dominates Islamic banking literature (Dar, Harvey, \& Presley, 1999; Dar \& Presley, 2000; Farooq, 2007; Kayed, 2012; Sadr, 1999). The advocates of Islamic banking argue that participatory financing is the essence of Islamic banking and represent the true spirit of the Islamic banking system (Ahmad, 2000; Chapra, 2000; Dusuki, 2007; Mansoori, 2011; Nouman \& Ullah, 2014, 2016; Siddiqi, 1983, 1985). While the non-participatory modes of financing (also called trade-based financing modes), are acceptable only in the situations where participatory arrangements are clearly not suitable. For example, in the case of consumer or very small loans (Khan, 2010; Also see Kuran, 2004; Usmani, 2002; Warde, 2000; Zaher \& Hassan, 2001). They claim that participatory financing arrangements are preferable to the non-participatory arrangements for several reasons, including their risk sharing features (Dar \& Presley, 2000; Ebrahim \& Safadi, 1995; Farooq, 2007). The non-participatory modes especially Mudarabah and Ijarah are criticized, which is justified to some extent on the basis that their net result is materially same as that of the interest-based borrowing when these are used within the framework of the conventional benchmarks like LIBOR etc. (Usmani, 2002, p. 165). Therefore, the Shariah supervisory boards have conceded that these are not the ideal models of financing and should only be used in case of need, with full observation of the Shariah prescribed conditions (Usmani, 2002, p. 165; 2007, p. 20). Moreover, this allowance should not be taken as a permanent rule for all sorts of transactions and the entire operations of Islamic Banks should not revolve around it (Usmani, 2002, p. 165). Furthermore, the basic philosophy of Islamic finance cannot be translated into reality unless Islamic banks expand the use of participatory financing (Sadique, 2012; Siddiqi, 1983; Usmani, 2002, p. 3; 2007, p. 240).

\subsection{Partici patory financing in the practices of Islamic banks}

The Islamic financial institutions (IFIs), particularly Islamic banks, adopt par- 
ticipatory financing modes for the scheme of deposits, especially for term deposit accounts. However, contrary to the expectations of advocates of Islamic finance, they tend to avoid participatory financing as the main financing scheme (See for example, Ahmed, 2011; Ariff, 1988; Ariss, 2010; Asutay, 2007; Dusuki, 2007; Jaffar, 2010; Lewis, 2008; Shahid, Shagufta, Ahmad, Ahmad, \& Shafique, 2015; Shinsuke, 2012; Siddiqi, 1985; Sugema, Bakhtiar, \& Effendi, 2010; Vahed \& Vawda, 2008; Vogel \& Hayes, 1998; Yousef, 2004; Zandi, Ariffin, \& Shahabi, 2012). By far, the non-participatory arrangements are the most dominant modes of financing in Islamic banks globally. The strong and consistent tendency of Islamic financial institutions to rely on debt-like instruments while investing funds is referred to as Murabahah syndrome by Yousef (2004).

Given the dominant reliance on non-participatory, Islamic finance cannot be referred to as risk-sharing in any meaningful sense (Khan, 2010). The non-participatory financing might be considered sufficient in meeting the requirement of Shariah compliance, but these are clearly insufficient to achieve the specific objectives of the Islamic finance and the broader goals of Shariah (Kayed, 2012, p. 3; Khan, 2011; Mansoori, 2011; Sadique, 2012; Siddiqi, 2006).

\section{Literature Review Methodology}

The present study employs insights form the extant literature using a systematic review approach. According to Tranfield, Denyer, and Smart (2003) a systematic review "provide[s] collective insights through theoretical synthesis" (p. 220). Systematic reviews aim to "answer a specific question, to reduce bias in the selection and inclusion of studies, to appraise the quality of the included studies, and to summarise them objectively" (Petticrew, 2001, p. 99). A number of articles in the management sciences field appearing in the top ranking journals employ the systematic review approach (See for example Farashahi, Hafsi, \& Molz, 2005; Knoben \& Oerlemans, 2006; Pittaway, Robertson, Munir, Denyer, \& Neely, 2004). The present study follows the same approach to answer the question 'what factors restrain participatory financing in Islamic banks?' This research applies and justifies systematic review on the following grounds:

First, According to Geraldi, Maylor, and Williams (2011) systematic review was traditionally employed in areas such as medicine to sum up findings based on quantitative and positivistic researches. However, the management research has diverse nature (Bryman, 1995) and follows differnt logic (Tranfield et al., 2003). Therefore, the quantitative analysis of the diverse sample of publication can result in the ontological and epistemological issues (Geraldi et al., 2011). Moreover, it may lead to the loss of the richness of the qualitative studies (Petticrew, 2001). The systematic review approach has "methodologies that are more flexible" (Petticrew, 2001, p. 98), accounting 
for the different conceptualisations and epistemologies. Moreover, it employs the qualitative reasoning of the reviewed studies (Geraldi et al., 2011).

Second, according to Petticrew (2001) good quality systematic reviews are superior over the traditional narrative review in the following ways:

- Systematic reviews always strive to answer a clear research question or test a stated hypothesis,

- good quality systematic reviews strive to locate all relevant studies,

- $\quad$ such reviews have an explicit criteria for deciding which studies to be included which helps in limiting the reviewer's selection bias,

- these examine the methods employed in the selected studies in a systematic manner to assess the quality of the studies. Moreover, it examines the potential biases and differences in the studies' results, and

- conclusions of such studies are based on the methodologically sound studies

Third, the objective of the study is to integrate the diverse literature to develop a holistic framework by synthesizing different explanations provided for the under utilization of participatory financing in the extant literature. Thus systematic review being "a method of locating, appraising, and synthesising evidence" (Petticrew, 2001) proves to be the most appropriate approach in this regard.

\subsection{Sam ple selection}

The systematic review strives to locate all relevant studies (Petticrew, 2001). For this purpose systematic review entails well defined criteria for searching and identifying the extant literature (Armitage \& Keeble-Ramsay, 2009). Furthermore, it require an explicit criteria for deciding which studies to be included in the sample to reduce the selection bias (Petticrew, 2001; Petticrew \& Roberts, 2006). To ensure that the search process employed in this study had been comprehensive enough and the selected sample is fairly representative of the literature the following literature review methodology has been employed:

The Web of Science was used as a starting point of the search. Relevant papers containing the keywords: Musharakah, Mudarabah, participatory financing, participation, partnership, profit and loss sharing, pain share gain share, and risk sharing were identified using this database. Additionally, databases including Elsevier (Science Direct), Wiley Online Library, Jstor, Springer Link, Taylor \& Francis, and Emerald etc. were also searched using the above keywords. Moreover, archives of the key 
peer-reviewed scholarly journals on Islamic finance were explored to identify relevant publications. The in press articles were not considered. 1983 was considered as the starting point and the relevant literature published till 2017 were covered. Thus, the time span of the selected studies is 1983 to 2017.

The initial sample was refined through the following steps:

Step 1: Focus on the academic papers. Among the downloaded articles only the academic papers were considered. Many databases provide this option automatically by defining the article type.

Step 2: Focus on Islamic finance. Based on the analysis of the articles' abstracts, the sample was refined to publications explicitly related to Islamic finance. Publications that clearly did not aim at contributing to the Islamic finance at least in a broad sense were excluded from the sample, for example articles that were clearly focused on different knowledge areas such as agriculture and manufacturing industries.

Step 3: Focus on the rare utilization of participatory financing. Since this review paper is focusing on issues in participatory financing. Only those articles were considered that at least in a broad sense focus on the issue of the rare utilization of participatory financing.

Step 4: Checking completeness. To ensure that we do not miss a substantial number of relevant papers we cross-checked with the content of the selected papers through backward and forward chaining. In the backward chaining the references list of the each of the selected papers downloaded from the sources mentioned above was followed up to identify relevant articles cited therein. The same was done for the new papers identified via backward chaining. This helped us expand our literature from present into the past. On the other hand, for forward chaining we took each of our selected articles one by one and explored what other articles cite the particular article. The same process was repeated for the new identified articles as well. This process also known as 'citation searching' helps expand literature from past into present. Cross-checking via backward and forward chaining helped us identify a large number of additional articles complying with the selection criteria defined in step 1 to 3 . Few articles were not accessible because of deferent reasons. These articles were accessed by corresponding directly to their authors.

To reduce the likelihood of missing relevant studies, many books authored by the seminal authors and relevant edited books have also been consulted. Most of the books were available online while few had to be purchased from the local market. Similarly, for relevant conference papers, the key conferences on Islamic finance were identified and their proceedings were explored. After cross-checking our sample grew 
to 108 relevant research studies complying with the selection criteria defined in step 1 to 3 . Table 1 presents the breakup of the relevant studies identified till step 4 .

Step 5: The final filter. Finally, the sample was reduced to those research studies that explicitly focus on problems in the participatory financing arrangements or the constraints faced by Islamic financial institutions in adopting participatory financing arrangements while investing. This reduced our sample to 91 research publications meeting the selection criteria. Table 1 presents the breakup of the 91 studies included in the final sample. Similarly, Table 2 presents the year wise and nature wise classification of the selected publications.

Table 1: Overview of the Number and the Type of Selected Publications in the Refining Step 4 and 5

\begin{tabular}{|c|c|c|c|c|c|c|}
\hline $\begin{array}{c}\text { Refining } \\
\text { step \# }\end{array}$ & Books & $\begin{array}{c}\text { Chapters of } \\
\text { edited books }\end{array}$ & $\begin{array}{c}\text { Journal } \\
\text { articles }\end{array}$ & $\begin{array}{c}\text { IMF Work- } \\
\text { ing papers }\end{array}$ & $\begin{array}{c}\text { Conference } \\
\text { papers }\end{array}$ & Total \\
\hline Step 4 & 15 & 14 & 66 & 3 & 10 & 108 \\
\hline Step 5 & 11 & 14 & 55 & 3 & 8 & 91 \\
\hline
\end{tabular}

Table 2: Overview of the Final Sample of Selected Publications (Step 5)

\begin{tabular}{|c|c|c|c|}
\hline \multicolumn{2}{|c|}{ Publication Year } & \multicolumn{2}{c|}{ Type of Papers* } \\
\hline $1983-1989$ & 3 & Theoretical & 26 \\
\hline $1990-1996$ & 8 & Qualitative & 3 \\
\hline $1997-2003$ & 29 & Quantitative & 43 \\
\hline $2004-2010$ & 26 & Qual \& Quant & 3 \\
\hline $2011-2017$ & 25 & Literature Review & 5 \\
\hline
\end{tabular}

* Excluding Books

\section{Analysis of the Literature}

Following the approach of Marston and King (2006) the present study treats the selected research papers and books as documents, and analyzes them using the established qualitative research techniques. Moreover, the Qualitative Evidence Synthesis (QES) is applied for the analysis of the selected studies and development of the constraints framework. Paterson (2012) defines QES as 'the synthesis or amalgamation of individual qualitative research reports that relate to a specific topic or focus in order to arrive at new or enhanced understanding about the phenomenon under study'. The QES entails an interpretative process by which 'the constituent study texts can be treated as the multivocal interpretation of a phenomenon, just as the voices of different participants might be in a single qualitative study' (Zimmer, 2006). The QES 
provides a broad overview of a body of research, therefore it has the ability to reveal more powerful explanations that are provided in the individual studies (Hannes $\&$ Lockwood, 2012). Hence, synthesis often leads to the increased level of abstraction and generalizability of the research findings (Sherwood, 1999).

Several methods can be applied for the synthesis of the qualitative evidence including thematic synthesis, framework synthesis, narrative synthesis, grounded theory, and meta-analysis (Hannes \& Lockwood, 2012). The present study adopts the thematic synthesis method. The thematic synthesis follows a highly structured approach for the selection, organizing, and tabulation of the primary research data. It mainly entails listing the findings of selected studies and then combining them into similar descriptors or themes to develop a general description of the problem at hand (Hannes \& Lockwood, 2012). The thematic synthesis 'uses thematic analysis techniques, as well as adaptations from grounded theory and meta-ethnography, to identify themes across primary research studies. Synthesis component entails an iterative process of inductively grouping themes into overarching categories that capture the similarities, differences, and relationships between the themes' (Paterson, 2012, p. 17). The developers of the thematic synthesis view 'informing practice or policy' as the intended outcome of the thematic synthesis (See for example Harden et al., 2004; Thomas et al., 2007; Thomas et al., 2003).

Analysis of the selected publications followed three steps. The first two steps were concerned with the identification, while the third step involved the classification of the major factors restraining the adaptation of participatory financing.

- In the first step the selected 91 publications were independently reviewed and coded. Codes represent the constraints explicitly appearing in the selected publications.

- In the second step the dozens of codes that emerged in the first step were refined through constant comparisons within and between codes to ensure that they accurately reflect the constraints to participatory financing. A total of 24 constraints to participatory financing were identified from the codes extracted in the first step with the overlapping items either eliminated or combined. Table 3 reports the constraints to participatory financing.

- In the last step link between the constraints were identified, grouping them into the broad overall themes. The constraints identified in the second step were classified into three distinct categories including: uncertainty, low demand, and regulatory constraints (See section 3.5 for details). Our intention was to develop the typology of constraints by connecting the rather abstract concepts into the broader sets of constraints for better conceptualization and policy implications. Since the literature was divergent, with diverse studies focused on few specific issues. This helped us integrate the extant literature and produce a coherent view about constraints to participatory financing. 


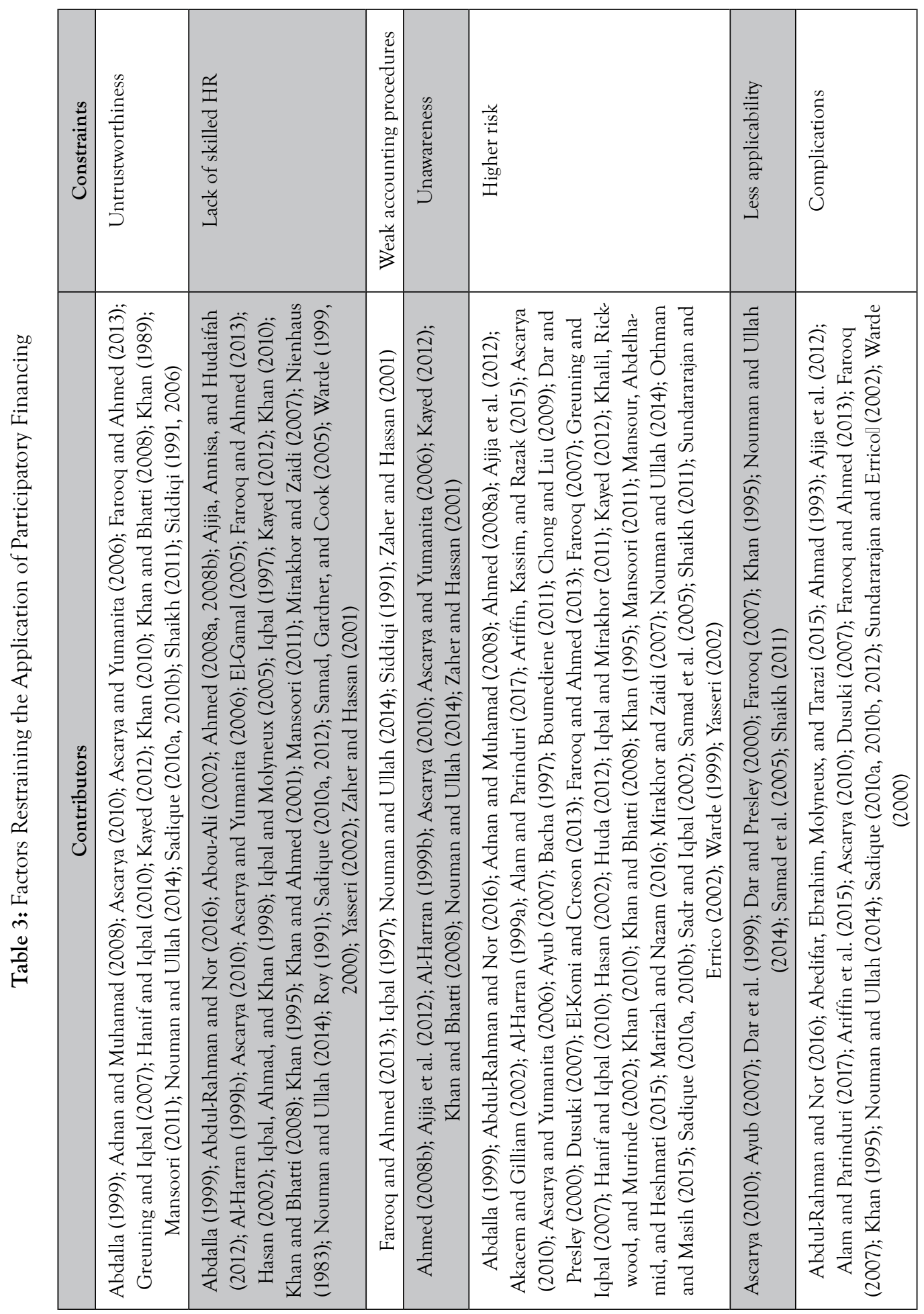




\begin{tabular}{|c|c|c|c|c|}
\hline 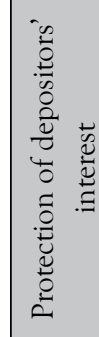 & 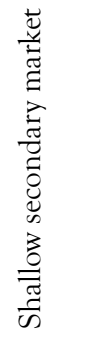 & 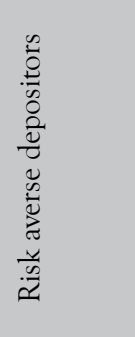 & 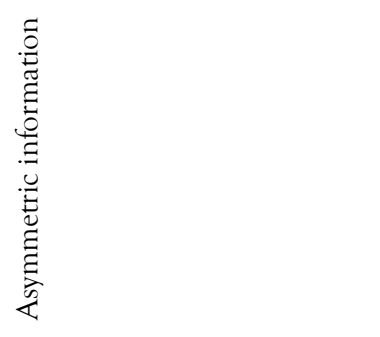 & 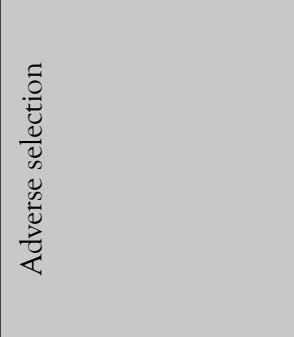 \\
\hline 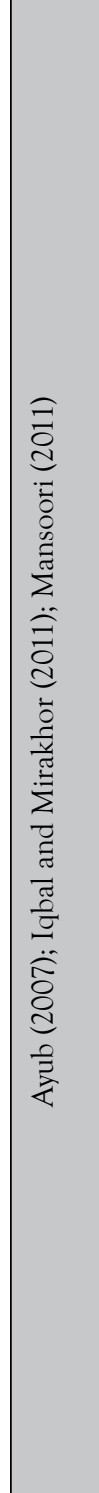 & 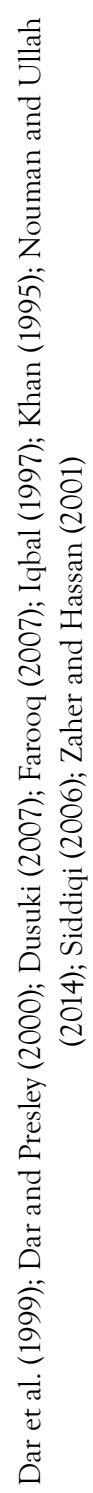 & 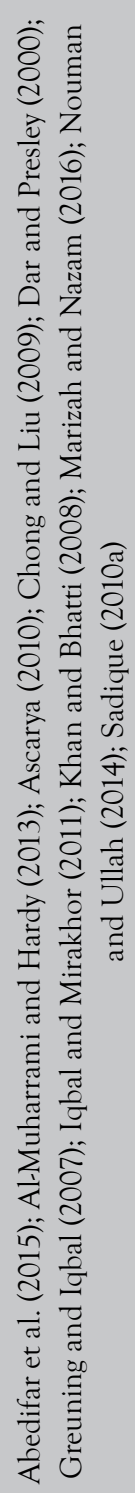 & 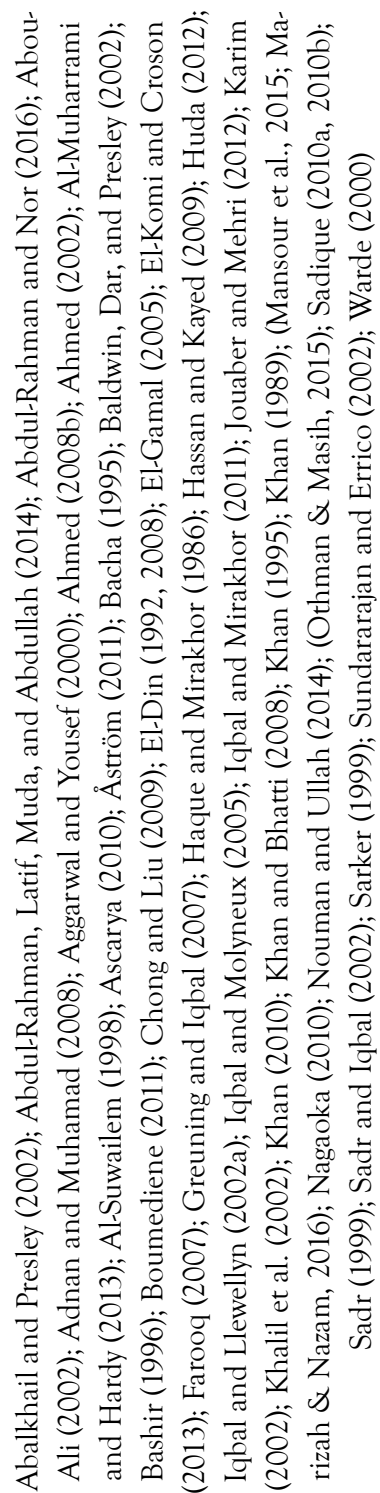 & 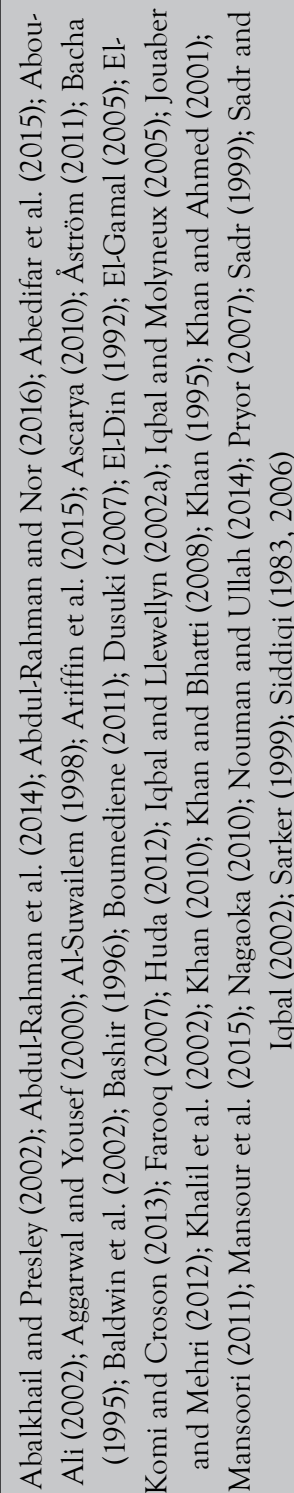 \\
\hline
\end{tabular}




\begin{tabular}{|c|c|c|c|c|c|}
\hline & 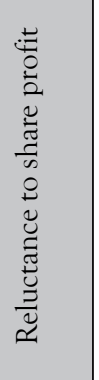 & 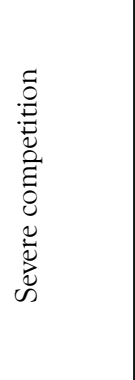 & 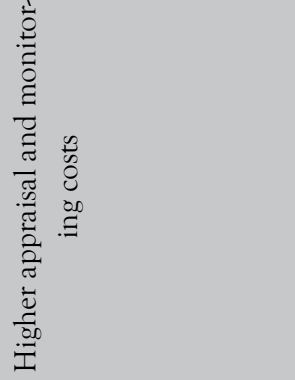 & 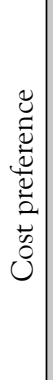 & 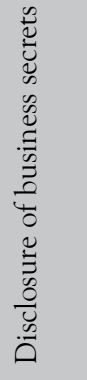 \\
\hline 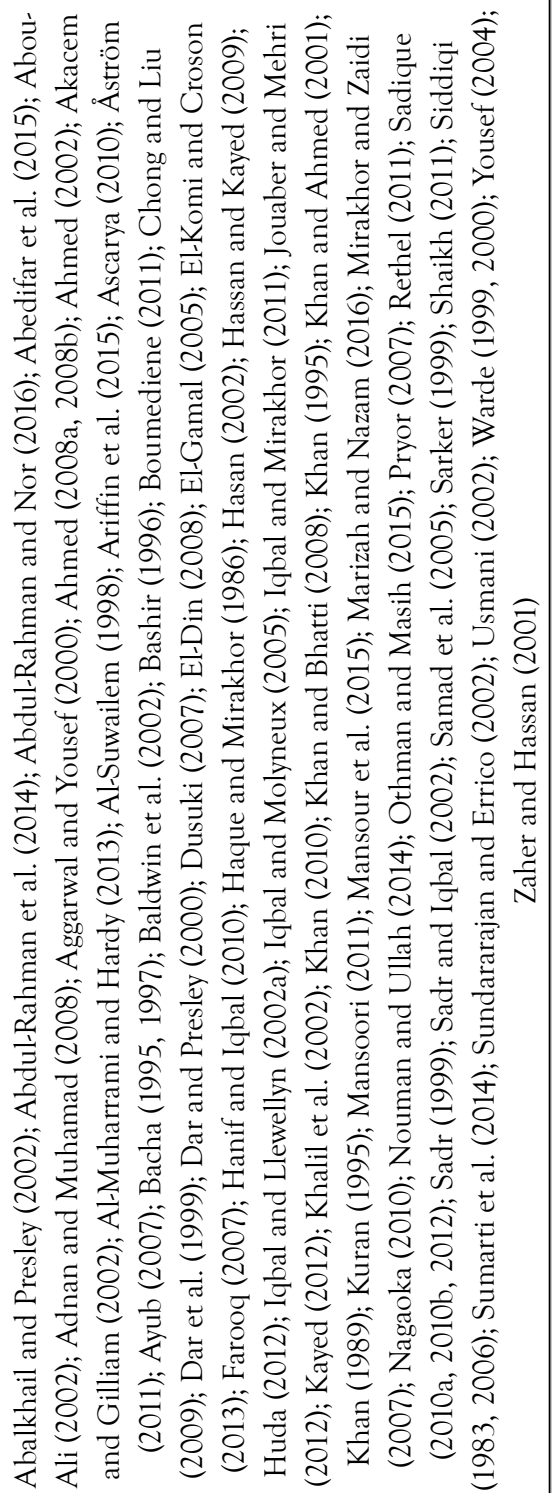 & 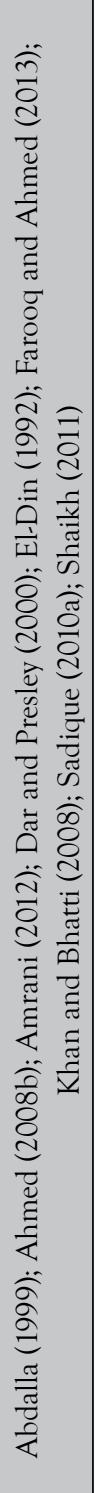 & 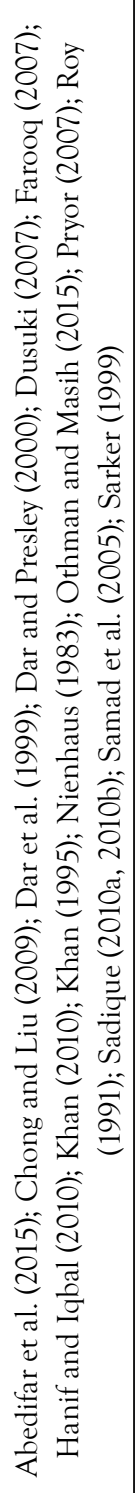 & 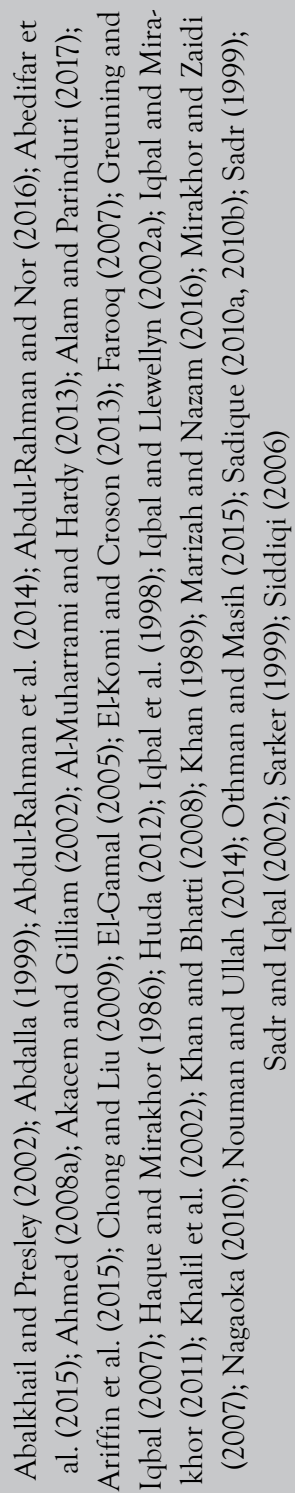 & 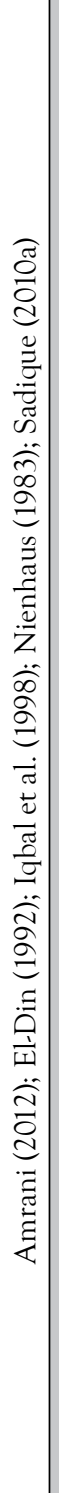 & 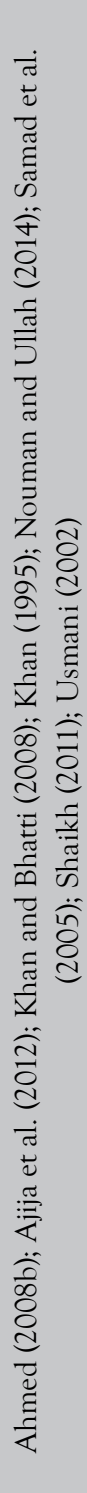 \\
\hline
\end{tabular}




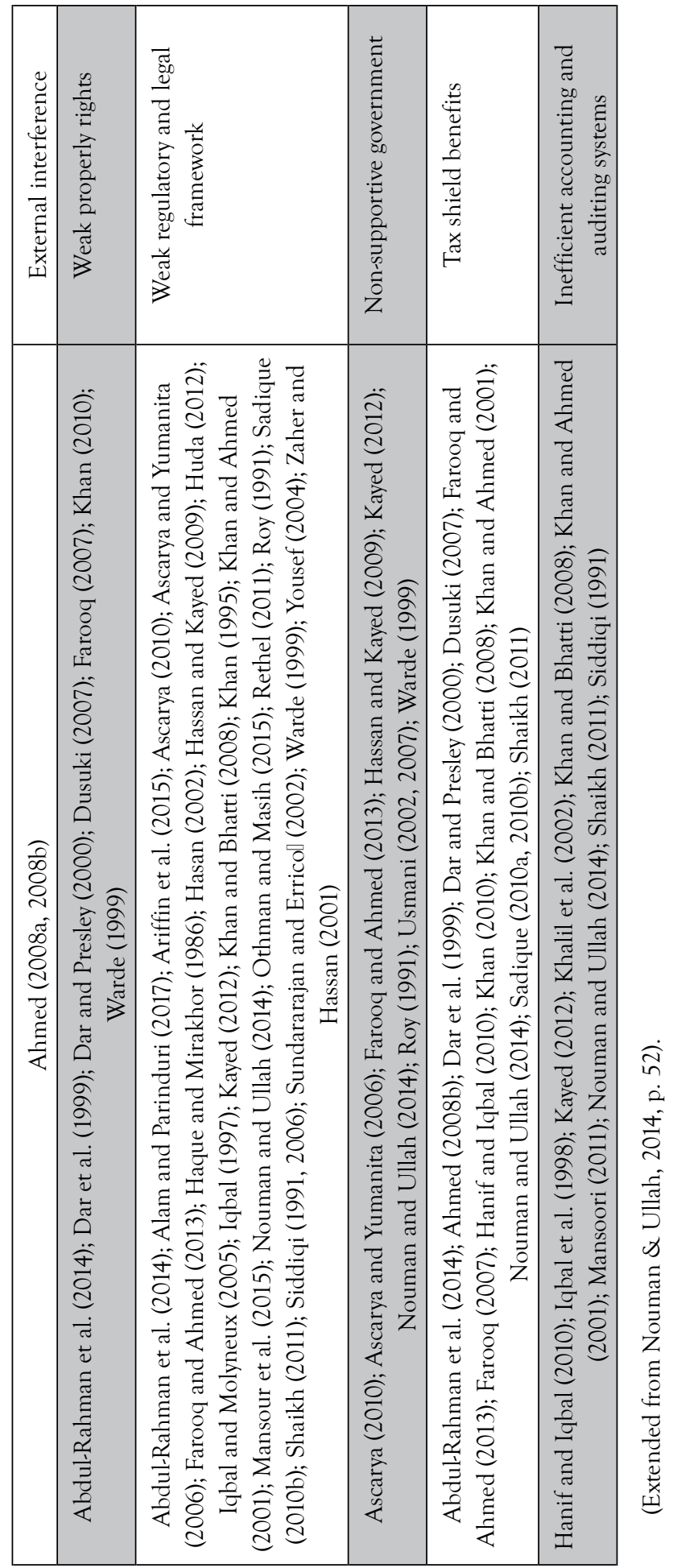




\section{Typology of the Constraints}

Table 3 indicates that a large set of abstract explanations for the less utilization of participatory financing has emerged from the analysis of the extant literature. All the distinct factors highlighted in the literature contribute together towards the less popularity of the participatory financing and put the non-participatory financing at a comparatively advantageous position. Although, the seemingly rather abstract elements are actually interconnected, it becomes difficult to conceptualize the big picture since the typology of constraints is missing. Therefore to bridge this gap a coherent framework has been proposed that outlines the typology of constraints participatory financing. This framework develops three distinct categories of the constraints namely uncertainty, low demand, and regulatory hurdles (See Figure 1).

The novel coherent constraints framework highlights that there are mainly three facets of lower preference for participatory financing. First, there are several factors in the contemporary business settings, prevailing social setting, and the bank's internal environment that underpin uncertainty in the success of participatory financing ar-

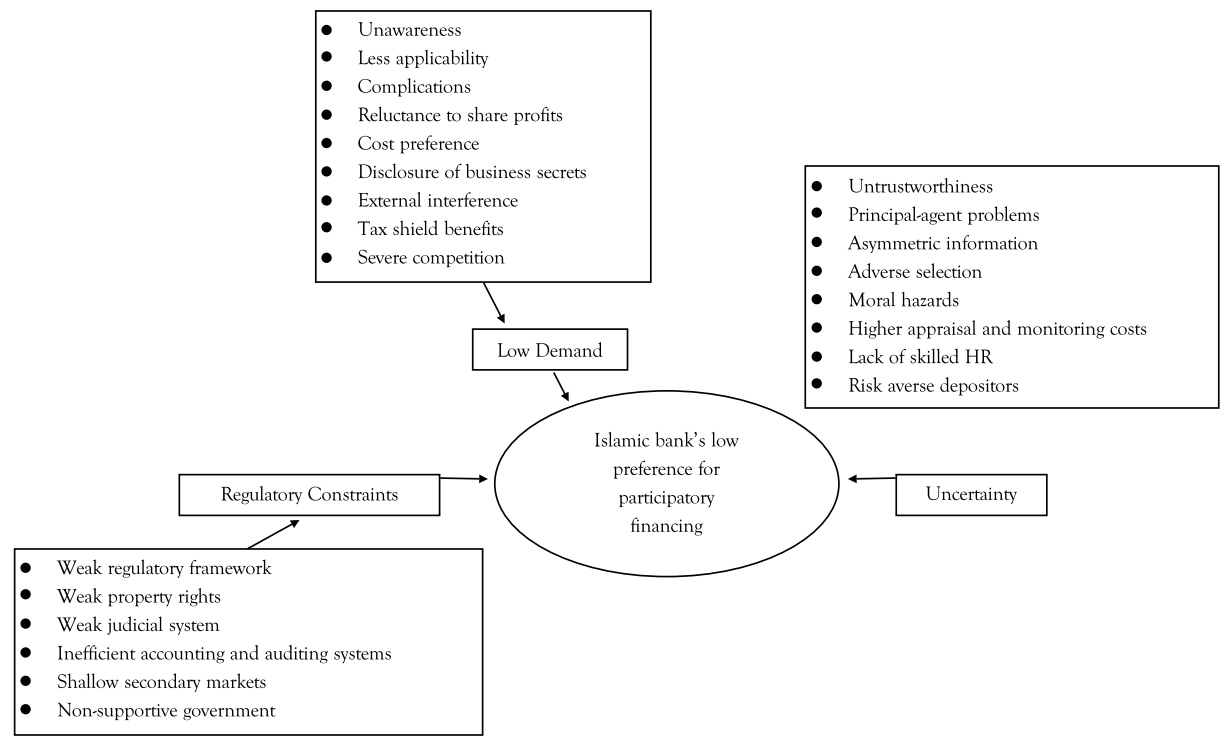

Figure 1: Demand, Regulation, and Uncertainty Framework

rangements. Second, there is a lower demand for participatory financing in the market i.e., entrepreneurs prefer to use non-participatory arrangements for financing their ventures due to the inherent restraining characteristics of the participatory financing arrangements. Finally, there are certain factors in the regulatory framework that restraint the extensive utilization of participatory financing arrangements by Islamic 
banks. Regulatory hurdles, as suggested by Abdul-Rahman et al. (2014), are a set of restraining factors derived from the regulatory structures, courts, laws, and government agencies exerting conformance pressures and shaping the lower preference of Islamic banks for participatory financing. Following is the detailed discussion on the three constructs of the constraints framework.

\section{a. Uncertainty}

According to Khan and Bhatti $(2008$, p. 49) the practical application of participatory financing has always been restricted by the business ethics constraints and operational difficulties in the Islamic banking industry. The current economic structure is biased, supporting the interest-based (and the non-participatory) system rather than the participatory paradigm (Sadique, 2010a). There are several factors in the contemporary business settings that induce uncertainty in participatory financing arrangements and in turn restrain their application in the Islamic banking industry (Khan, 1995). Table 4 summarizes the factors that induce uncertainty in the successful commencement and operation of participatory financing in Islamic banking.

Fairness is important to success of partnership arrangements. An experimental study by Zhou and Wu (2011) which employed different economic games suggests that people have increased demand for fairness when they have to share losses with

Table 4: Factors Inducing Uncertainty in Participatory Financing Arrangements

\begin{tabular}{|c|}
\hline Low levels of reliability and trustworthiness in the market \\
\hline Asymmetric information \\
\hline Adverse selection \\
\hline Moral hazards \\
\hline $\begin{array}{c}\text { Participatory financing arrangements involve higher project appraisal and monitoring costs which } \\
\text { induces Islamic banks to bear additional costs of operation. }\end{array}$ \\
$\begin{array}{c}\text { Projects and clients to be financed through participatory financing arrangements require to be eval- } \\
\text { uated very carefully for which managerial skills and expertise is required. However, there is a lack of } \\
\text { skilled human resource in the Islamic banks. }\end{array}$ \\
\hline Depositors of Islamic banks are risk averse. Thus, investing their funds in risky projects could \\
prompt their depositors to withdraw their funds.
\end{tabular}

others. People demand justice in wealth allocation in both the loss and gain domains, but this preference in the context of loss sharing might not be the same as in the context of gain sharing (Zhou \& Wu, 2011). Potential losses have greater impact on fairness preference and choice behavior than the equivalent gains (Kahneman, 1992; Tversky \& Kahneman, 1981). Therefore, unfairness in division schemes would 
originate stronger reactions (higher rejection rates) among partners in loss sharing compared to gain sharing.

Similarly, Williamson in the Transaction Cost Theory suggests two other important behavioral premises of human agents: bounded rationality and opportunism (Williamson, 1981, 1985, 1993). Bounded rationality means that although human beings intend to behave rationally, their rationality is limited by their ability to "formulate and solve complex problems and to process information" (Williamson, 1981). Therefore, in (neo-) classical economic sense, their decisions are hardly ever optimal (Simon, 1945). Opportunism may be defined as "self-interest seeking with guile" (Williamson, 1981, 1993), which means that parties are willing to provide incomplete or false information to complete a transaction that will provide them with advantage (Alaghehband, Rivard, Wu, \& Goyette, 2011).

Given bounded rationality, opportunism and increased demand for fairness under adversity, participatory financing arrangements are more exposed to compatibility, conflicts, and other contracting problems. Therefore, existence of a supportive and cooperative social environment is conducive to the successful operation of the participatory paradigm (Hassan \& Kayed, 2009). In the nutshell, high moral standards in the society are prerequisite for the success of participatory financing arrangements. These contracts are not workable in an environment which lacks honest and fair dealings (Mansoori, 2011). The lack of reliability and trustworthiness in the society leads to agency problems in participatory financing including the asymmetric information, adverse selection, and moral hazards problems.

Asymmetric information is a situation that arises when insufficient knowledge of one party involved in the transaction about the other one, makes it impossible to take accurate decisions while conducting a transaction (Mishkin \& Eakins, 2011). Since participatory financing arrangements are formulated in the form of principal-agent arrangements (Bashir, 1996), these are prone to the asymmetric information problem. The agent (an entrepreneur who seeks funds) being the insider (active) party has better knowledge about the project they wish to undertake. While the principal (a bank which provides the funding needed to initiate the project) being the outsider (passive) party usually has less knowledge about the potential returns and the associated risks of the project than the agent does (Khalil et al., 2002). According to Nouman and Ullah (2014) the asymmetric information creates problems in the participatory arrangements on two fronts: before the project is initiated (i.e., adverse selection) and after the initiation of the project (i.e. moral hazard).

Adverse selection is the problem faced due to asymmetric information before occurrence of the transaction (Mishkin \& Eakins, 2011, p. 25). Borrowers have 
better inside information about themselves (including their abilities and intentions) and project (including its potential returns and likelihood of success), but they may not credibly signal it to the bank in the wake of exploiting interest of bank for their own benefits (Iqbal \& Molyneux, 2005; Sarker, 1999). Since it is difficult for banks to determine the quality of a loan applicant, this creates several adverse selection problems (Mills \& Presley, 1999).

Given the asymmetric information, the adverse (undesirable) selection is more likely to occur in case of participatory arrangements because the following type of borrowers actively seek funds on partnership basis and are therefore more likely to be selected:

1. The borrowers expecting their projects to provide low profits but high non-monetary benefits prefer participatory arrangements because they expect to realize high total returns at artificially low cost of capital (Pryor, 1985).

2. The borrowers expecting high profit from a risky project prefer participatory arrangement (Sarker, 1999) because their risk will be shared or even completely borne by bank (i.e., in case of Mudarabah because if the project fails, losses will be exclusively borne by the bank whereas, the entrepreneur will lose his efforts).

3. When the ratio of profit-sharing is decided on the basis of expected profit, potential borrowers inflate their declared profit expectation in the hope of profit sharing ratio being set low by bank (Nienhaus, 1983).

Due to adverse selection it is more likely that funds might be lent to inappropriate applicants, banks decide not to invest on partnership basis even though there are suitable parties (with promising projects) in the marketplace (Nouman \& Ullah, 2014).

On the other hand, moral hazard is the problem faced due to asymmetric information after a project is initiated (Mishkin \& Eakins, 2011, p. 26). Moral hazard in participatory arrangements is the risk (hazard) that the working partner might involve in activities that are undesirable (immoral) from the bank's point of view (Nouman $\&$ Ullah, 2014). These problems are associated with the under reporting or artificial reduction of the actual profit and the difficulty of observing the entrepreneur's actions (Amrani, 2012).

Since, participatory financing arrangements are formulated in the form of principal-agent arrangements, the moral hazard problems in such contracts are similar to those found in agency relationships (Ahmed, 2002, p. 43). The Principal-agent problem arises when the entrepreneur (agent) involves in activities that maximizes his interest at the cost of bank's (principal) interest. The moral hazard problem arises in 
such set-ups if an agent is slack about the firm's management, misuses the funds, and is not honest (Mishkin, 1995). Mudarabah contracts are more vulnerable to agency problems and moral hazards compared to Musharakah contacts since financier has no right to interfere in the business but is required to bear all losses (Bacha, 1997; Kayed, 2012). The prevalence of poor systems of accounting and auditing in most of the Muslim countries, and failure of the judicial systems in helping financial systems in case of default strengthen the probability of moral hazard in participatory financing arrangements.

The problem of adverse selection and moral hazards induce the risk of default in the participatory financing arrangements which in turn harm the interest of depositors. The Islamic banks would therefore need to evaluate the projects and clients to be financed through participatory financing very carefully. Moreover, they need to incur costly monitoring expenses to ensure that the behavior of entrepreneur is consistent with the bank's interests. The additional dead weight costs in pre-contract project appraisal and post-contract monitoring to control the adverse selection and moral hazards make partnership agreements costly compared to the non-participatory arrangements (Sarker, 1999). Furthermore, the pre-contract project appraisal and post-contract monitoring is not only expensive but also non feasible for Islamic banks because it requires managerial skills and expertise. However, there is a serious lack of qualified credit personnel for the evaluation and monitoring of the projects in the Islamic banks (Al-Harran, 1999b; Kayed, 2012). Moreover, depositors of Islamic banks are risk averse. Thus, investing their funds in risky projects could prompt their depositors to withdraw their funds (Al-Muharrami \& Hardy, 2013).

In the nutshell, there are several distinct but interdependent operational factors in the contemporary business settings that underpin uncertainty in the participatory financing arrangements, which in turn restrict the commencement and successful operation of the participatory financing arrangements.

\section{b. Lower demand}

Few scholars view the problem from a different dimension. According to Amrani (2012) the extant literature grants the contractual choice exclusively to the bank, assuming that the avoidance of the participatory financing comes from the supply side in the market. However, there are many factors on the demand side that hinder the application of participatory financing. Table 5 summarizes the factors that hamper the demand for participatory financing.

According to Ayub (2007), Kayed (2012), and Usmani (2007), participatory financing arrangements have been widely criticized for being "old instruments" that 
are neither fitting for contemporary financial needs nor comparable with what the state-of-the-art conventional banking can offer. The reluctance of the Islamic banks

Table 5: Factors Contributing to Lower Demand for Participatory Financing

\begin{tabular}{|c|}
\hline Participatory financing arrangements are less applicable. \\
\hline More complicated to structure and deal with partnership financing. \\
\hline Profitable businesses are not willing to share their expected high profits with Islamic banks. \\
\hline Businesses are interested in the cost; not in the mode of financing. \\
Low demand for participatory financing because it may disclose business operations and its secrets \\
to the financier and other parties. \\
\hline Entrepreneurs prefer to maintain independence and avoid external interference. \\
\hline Unfair treatment in taxation: Interest is tax deductible but profits are not. \\
\hline Lack of understanding and knowledge in the society regarding the fundamentals of the Islamic \\
finance and banking. \\
\hline $\begin{array}{c}\text { Due to severe competition from conventional banks and other financial institutions, Islamic banks } \\
\text { have to offer comparable products }\end{array}$ \\
\hline
\end{tabular}

to adopt participatory financing arrangements have been widely attributed to the construct and the disposition of the participatory financing arrangements themselves (Kayed, 2012) which in turn lead to the lower demand for the participatory financing. For example, according to Samad et al. (2005) and Nouman and Ullah (2014) Musharakah and Mudarabah are less applicable. Moreover, these arrangements are more complicated to structure and deal with (Sadique, 2010a, 2010b, 2012; Warde, 2000).

Amrani (2012) and few other scholars are of the view that customers (borrowers) refuse the participatory financing arrangements for a given quality of their projects, since these arrangements become more expensive to the entrepreneurs if their profitability exceeds a certain level (Amrani, 2012). Therefore, they prefer non-participatory financing and interest bearing financing since they do not have to share their high business profits with the financier. Additionally, unfair treatment in taxation also contributes towards comparatively higher cost of participatory financing arrangements. Profit is taxed while interest is exempted (Dar \& Presley, 2000). Thus, the tax shield benefit feature of the interest bearing modes of finance makes participatory financing the least attractive option (Khan, 2010). Furthermore, the need of rigorous accounting and periodic audits make participatory financing more complicated to deal with. Moreover, entrepreneur loses exclusive control over his business (Ahmed, 2008a). Thus, many entrepreneurs reject participatory financing because they do not want to disclose their operations and trade secrets to the financiers (Shaikh, 2011) and tend to protect their business from external interference (Ahmed, 2008a). 
In the nutshell, there are many inherent factors in the standard participatory arrangements that make participatory financing a less attractive option for profitable and stable businesses. Therefore, Islamic banks need to develop incentive compatible financing products based on participation principles to promote participatory financing in the contemporary business environment.

\section{c. Regulatory constraints}

According to Yousef (2004) the economic and legal mechanisms underpins financial systems around the globe. These economic and legal mechanisms depend on the political structures, regulatory institutions, legal tradition, and institutional variables such as bureaucratic quality, corruption, and expropriation risk. The presence of a sound regulatory framework is prerequisite for the effective regulation of Islamic financial institutions (Wilson, 2003), and growth of participatory financing (Haque \& Mirakhor, 1986). A sound regulatory framework for Islamic banking comprises of various components including the securities law, Shari'ah law, insolvency law, property law, business law, tax law. common law, civil law, and employment law (Abdul-Rahman et al., 2014). Following are the features of a sound regulatory framework (ISRA., 2011):

1. A supportive financial environment that assists and promotes the development of the industry.

2. A sound legal framework offering a comprehensive and proficient system conducive to the successful operation of the participatory financing arrangements.

3. A reliable and credible forum for clearing the legal disputes of the parties involved in the Islamic financing arrangements.

However, a sound regulatory framework is missing in Muslim countries (Haque \& Mirakhor, 1986). For example, in most of the Muslim countries property rights are neither properly defined nor well protected (Abdul-Rahman et al., 2014; Warde, 1999), the judicial system is not capable of enforcing the terms of the contacts (Warde, 2000), secondary market for Islamic financial instruments is shallow and illiquid (Dar \& Presley, 2000), the taxation policies are biased (Sadique, 2010a), the auditing and accounting systems are weak and inefficient (Iqbal, 1997). Thus, leaving participatory financing a less attractive option for Islamic banks. Table 6 summarizes the regulatory factors that restrain the application of participatory financing.

Prudential regulations imposed by the regulatory authorities also play an important role in restraining the application of participatory financing on a large scale. Sound regulations help in mitigating the problems of asymmetric information. On the other hand, regulations that are over restrictive can prove counterproductive, since it may 
Table 6: Regulatory Factors Restraining the Application of Participatory Financing

\begin{tabular}{|c|}
\hline Absence of a supportive regulatory framework \\
\hline Banking laws enforce rules and controls on the allocation of bank's funds in direct investment \\
\hline Lack of properly defined or protected property rights in Muslim countries \\
\hline Weak judicial system in Muslim countries \\
\hline Inefficient accounting and auditing systems \\
\hline Lack of sound accounting procedures and standards consistent with the Islamic laws \\
\hline Illiquid and shallow secondary market for Islamic financial instruments \\
\hline The Islamic bank acting as managing partner for depositors is bound to protect the interest of \\
depositors and to invest their money in less risky avenues. \\
Lack of commitment and support from government \\
\hline
\end{tabular}

restrict the number of products being offered by Islamic banks, increase transaction costs, and decrease financial efficiency (Wilson, 2003). Islamic banks are exposed to the equity investment risk that arises from investing funds on participation basis (Song \& Oosthuizen, 2014). Moreover, the value of their deposits is not guaranteed. The value of deposits may become at stake in the event of severe losses (Wilson, 2003). In the wake of securing depositors interests the regulatory bodies impose various controls on the allocation of funds in direct investments involving profit and risk sharing (Abdalla, 1999; Abou-Ali, 2002; Khan, 2010). Therefore, Islamic banks are bound to invest their money in less risky avenues (Ayub, 2007; Iqbal \& Mirakhor, 2011; Mansoori, 2011).

In case of participatory financing arrangements bank shares in profits and losses of venture. It is not a matter of concern if the bank is allowed, and is able to keep a close eye on the operations of the firm. However, suitable monitoring mechanisms have not been devised yet for the participatory financing arrangements, especially for Mudarabah arrangements where financier does not have the control right (Dar \& Presley, 2000). Since, the bank cannot control the entrepreneur who manages the venture being financed through Mudarabah. Moreover, the bank cannot reduce the risk in participatory financing by requiring guarantee or collateral (El-Qorchi, 2005). Therefore, supportive prudential regulations are crucial for the successful operation of the participatory financing in the modern world (Ascarya, 2010; Dar \& Presley, 2000).

In Pakistan various Mudarabah laws attempts to outline a basic regulatory framework including the Mudarabah companies and Mudarabahs Ordinance 1980, the Mudarabah Rules 1981, the State Bank of Pakistan's prudential regulations, and The Guidelines for Issuance of Musharakah Certificates for Mudarabah. However, standardized participatory financing contracts or bylaws need to be constructed keeping 
in view the legal frameworks of Islamic countries (Dar \& Presley, 2000).

\section{Conclusion}

The constraints framework strengthens the axiom that Islamic finance is a dependent system requiring an economy based on Islamic setting. The viability of Islamic finance especially participatory financing depends on the presence of a "true Islamic state" where its religious, social, political, economic, legal, and educational institutions complement each other and function as a whole towards the accomplishment of common values and the desired goals (Hassan \& Kayed, 2009). Moreover, it highlights the factors in the contemporary social, economic, and regulatory settings that strengthen the non-cooperative and risk-averse attitudes and hinder the viability of the participatory financing. Compared to participatory financing, the non-participatory financing is more consistent with the conventional banking traditions in the present setting. Banking culture, professional orientation of staff, similarity of products and services being offered, laws and regulations, and premises of competition, all put the non-participatory modes of financing at a comparatively advantageous position (Khan, 1995).

Given the lack of trustworthiness and cooperation in the market, lower demand for the participatory financing, and absence of supportive regulatory framework and enabling institutions, the main challenge faced by the Islamic financial service industry is the development of a mechanism that would reveal the fruits of Islamic finance to the global economy (Hassan \& Kayed, 2009). Thus, there is serious need of policy implications, institutional reforms, and introduction of incentive compatible contracts based upon participation principle. Unless serious steps are taken by Islamic banks, academia, and regulatory and legal bodies, the non-participatory financing will continue to dominate the operations of Islamic banks.

\section{References}

Abalkhail, M., \& Presley, J. R. (2002). How informal risk capital investors manage asymmetric information in profit/loss-sharing contracts. In M. Iqbal \& D. T. Llewellyn (Eds.), Islamic Banking and Finance: New perspectives on profit-sharing and risk (pp. 111-134). Cheltenham, UK. Northampton, MA, USA: Edward Elgar.

Abdalla, M. G.-E. (1999). Partnership (Musharakah): A New Option for Financing Small Enterprises? Arab Law Quarterly, 14(3), 257-267.

Abdouli, A. H. (1991). Access to finance and collaterals: Islamic versus Western banking Journal of King Abdulaziz University: Islamic Economics, 3(1), 55-62.

Abdul-Rahman, A., Latif, R. A., Muda, R., \& Abdullah, M. A. (2014). Failure and potential of profit-loss 
sharing contracts: A perspective of New Institutional, Economic (NIE) Theory. Pacific-Basin Finance Journal, 28, 136-151.

Abdul-Rahman, A., \& Nor, S. M. (2016). Challenges of profit-and-loss sharing financing in Malaysian Islamic banking. Malaysian Journal of Society and Space, 12(2), 39-46.

Abedifar, P., Ebrahim, S. M., Molyneux, P., \& Tarazi, A. (2015). Islamic banking and finance: Recent empirical literature and directions for future research. Journal of Economic Surveys, 29(4), 637-670.

Abou-Ali, S. (2002). Comments: How informal risk capital investors manage asymmetric information in profit/loss-sharing contracts. In M. Iqbal \& D. T. Llewellyn (Eds.), Islamic Banking and Finance: New perspectives on profit-sharing and risk (pp. 135-138). Cheltenham, UK. Northampton, MA, USA: Edward Elgar.

Adnan, M. A., \& Muhamad. (2008). Agency problems in mudarabah financing: The case of Sharia (Rural) banks, Indonesia. In M. Obaidullah \& H. S. H. A. Latiff (Eds.), Islamic finance for micro and medium enterprises (pp. 107-130): Islamic Research \& Training Institute, Islamic Development Bank.

Aggarwal, R. K., \& Yousef, T. (2000). Islamic banks and investment financing. Journal of Money, Credit and Banking, 32(1), 93-120.

Ahmad, A. (1993). Contemporary practices of Islamic financing techniques Jeddah, Saudi Arabia: IRIT, Islamic Development Bank.

Ahmad, K. (2000). Islamic Finance and Banking: The challenge and prospects. Review of Islamic Economics, $9,57-82$.

Ahmed, G. A. (2008a). The implication of using profit and loss sharing modes of finance in the banking system, with a particular reference to equity participation (partnership) method in Sudan. Humanomics, 24(3), 182-206.

Ahmed, G. A. (2008b). Islamic micro-finance practice with a particular reference to financing entrepreneurs through equity participation contracts in Sudanese banks. In M. Obaidullah \& H. S. H. A. Latiff (Eds.), Islamic finance for micro and medium enterprises (pp. 75-105): Islamic Research \& Training Institute, Islamic Development Bank.

Ahmed, H. (2002). Incentive-compatible profit-sharing contracts: a theoretical treatment. In M. Iqbal \& D. T. Llewellyn (Eds.), Islamic Banking and Finance: New perspectives on profit-sharing and risk (pp. 40-54). Cheltenham, UK. Northampton, MA, USA: Edward Elgar.

Ahmed, H. (2011). Maqasid al-Shari'ah and Islamic financial products : A framework for assessment. ISRA International Journal of Islamic Finance, 3(1), 149-160.

Ajija, S. R., Annisa, E., \& Hudaifah, A. (2012). How do Islamic banks optimize profit and loss sharing arrangements? . Paper presented at the Fourth Research Forum inIslamic Banking Bank Indonesia.

Akacem, M., \& Gilliam, L. (2002). Principles of Islamic banking: Debt versus equity financing. Middle 
East Policy, 9(1), 124-138.

Al-Harran, S. (1999a). Introduction: Cases in Islamic Finance. Arab Law Quarterly, 14(3), 193-202.

Al-Harran, S. (1999b). New strategic alliances between Islamic financial institutions, international university students and entrepreneurs to implement musharakah financing to meet the challenges of the 21st century Arab Law Quarterly, 14(3), 268-281.

Al-Muharrami, S., \& Hardy, D. C. (2013). Cooperative and Islamic Banks; What can they learn from each other? International Monetary Fund Working Paper, WP/13/184.

Al-Suwailem, S. (1998). Venture capital: A potential model of musharakah Journal of King Abdulaziz University: Islamic Economics, 10, 3-20.

Alaghehband, F. K., Rivard, S., Wu, S., \& Goyette, S. (2011). An assessment of the use of Transaction Cost Theory in information technology outsourcing. Journal of Strategic Information Systems, 20, 125-138.

Alam, N., \& Parinduri, R. A. (2017). Do Islamic banks shift from mark-up to equity financing when their contracting environments are improved? Applied Economics Letters, 24(8), 545-548.

Amrani, F. (2012, June 28-29). Financing cost and risk sharing in Islamic finance: A new endogenous approach. Paper presented at the 29th International Symposium on Money, Banking and Finance, NantesFrance.

Ariff, M. (1988). Islamic banking. Asian-Pacijlc Economic Literature, 2(2), 48-64.

Ariffin, N. M., Kassim, S. H., \& Razak, D. A. (2015). Exploring application of equity-based financing

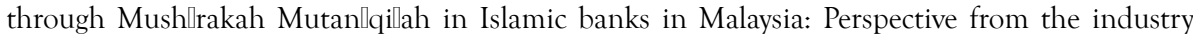
players. International Journal of Economics, Management and Accounting, 23(2), 241-261.

Ariss, R. T. (2010). Competitive conditions in Islamic and conventional banking: A global perspective. Review of Financial Economics, 19, 101-108.

Armitage, A., \& Keeble-Ramsay, D. (2009). The rapid structured literature review as a research strategy US-China Education Review, 6(4).

Ascarya. (2010). The lack of profit-and-loss sharing financing in Indonesia's islamic banks revisited. Review of Indonesian Economic and Business Studies, 1(1), 57-80.

Ascarya, \& Yumanita, D. (2006). The lack of profit and lost sharing financing in Indonesian Islamic banks: Problems and alternative solutions. Paper presented at the INCEIF Islamic Banking and Finance Educational Colloquium, KL Convention Center, Kuala Lumpur, Malaysia.

Åström, Z. H. O. (2011). Enhancing the structure of Islamic banking by lessening the asymmetric information pertaining to profit and loss sharing instruments. Paper presented at the 8th International Conference on Islamic Economics and Finance, Qatar National Convention Center, Qatar.

Asutay, M. (2007). Conceptualisation of the second best solution in overcoming the social failure of 
Islamic finance: Examining the overpowering of homoislamicus by homoeconomicus. IIUM Journal in Economics and Management, 15(2), 167-195.

Ayub, M. (2007). Understanding Islamic Finance. England: John Wiley \& Sons Ltd,.

Bacha, O. I. (1995). Conventional versus mudarabah financing: An agency cost perspective. Journal of Islamic Economics, 4(1\&2), 33-49.

Bacha, O. I. (1997). Adapting mudarabah financing to contemporary realities: A proposed financing structure. The Journal of Accounting, Commerce EF Finance, 1(1).

Baldwin, K., Dar, H. A., \& Presley, J. R. (2002). On determining moral hazard and adverse selection in the Islamic firm. In H. Ahmad (Ed.), Theoretical Foundations of Islamic Economics (Vol. 1, pp. 145 166). Jeddah: IRTI, Islamic Development Bank.

Bashir, A. H. M. (1996). Investment under profit-sharing contracts: The adverse selection case. Managerial Finance, 22(5/6), 48-58.

Boumediene, A. (2011). Is credit risk really higher in Islamic banks? The Journal of Credit Risk, 7(3), 97-129.

Bryman, A. (1995). Research methods and organization studies. London, New York: Allen \& Unwin Pty.

Chapra, M. U. (1985). Towards a just monetary system Leicester, UK: The Islamic Foundation.

Chapra, M. U. (2000). Why has Islam prohibited interest: Rationale behind the prohibition of interest. Review of Islamic Economics, 9, 5-20.

Chong, B. S., \& Liu, M.-H. (2009). Islamic banking: Interest-free or interest-based? Pacific-Basin Finance Journal, 17, 125 - 144.

Dar, H. A., Harvey, D. I., \& Presley, J. R. (1999). Size, profitability, and agency in profit and loss sharing in Islamic banking and finance. Paper presented at the Second Harvard University Forum on Islamic Finance: Islamic Finance into the 21st Century, Cambridge, Massachusetts.

Dar, H. A., \& Presley, J. R. (2000). Lack of proØt loss sharing in Islamic banking: Management and control imbalances. International Journal of Islamic Financial Services, 2(2), 3-18.

Dusuki, A. W. (2007). The ideal of Islamic banking: A survey of stakeholders' perceptions. Review of Islamic Economics, 11(Special Issue), 29-52.

Ebrahim, M. S., \& Safadi, A. (1995). Behavioral norms in the Islamic doctrine of economics: A comment Journal of Economic Behavior and Organization, 27, 151-157.

El-Din, S. I. T. (1992). Debt and equity in a primary financial market: A theory with Islamic implications. JKAU: Islamic Economics, 4, 3-34.

El-Din, S. I. T. (2008). Income Ratio, Risk-Sharing, and the Optimality of Mudarabah. The Journal of King Abdulaziz University, Islamic Economics, 21(2), 37-59 
El-Gamal, M. A. (2005). Islamic bank corporate governance and regulation: A call for mutualization. Rice University.

El-Komi, M., \& Croson, R. (2013). Experiments in Islamic microlnance. Journal of Economic Behavior $\mathcal{E}$ Organization, 95, 252-269.

El-Qorchi, M. (2005). Islamic finance gears up. Finance and Develeopemt, 42.

ElGindi, T., Said, M., \& Salevurakis, J. W. (2009). Islamic alternatives to purely capitalist modes of finance: A study of Malaysian banks from 1999 to 2006. Review of Radical Political Economics, 41 (4), 516-538.

Farashahi, M., Hafsi, T., \& Molz, R. (2005). Institutionalized norms of conducting research and social realities: A research synthesis of empirical works from 1983 to 2002. International Journal of Management Reviews, 7(1), 1-24.

Farooq, M., \& Ahmed, M. M. M. (2013). Musharakah financing: Experience of Pakistani banks. World Applied Sciences Journal, 21(2), 181-189.

Farooq, M. O. (2007). Partnership, equity-financing and Islamic finance: whither profit-loss sharing? Review of Islamic Economics, 11(Special Issue), 22.

Geraldi, J., Maylor, H., \& Williams, T. (2011). Now, let's make it really complex (complicated): a systematic review of the complexities of projects. International Journal of Operations $\mathcal{E}$ Production Management, 31(9), 966-990.

Greuning, H. V., \& Iqbal, Z. (2007). Banking and the risk environment. In S. Archer \& R. A. A. Karim (Eds.), Islamic Finance: Regulatory Challenge (pp. 11-36). Singapore: John Wiley and Sons.

Hanif, M., \& Iqbal, A. M. (2010). Islamic financing and business framework: A survey. European Journal of Social Sciences, 15(4), 475-489.

Hannes, K., \& Lockwood, C. (Eds.). (2012). Synthesizing qualitative research: Choosing the right approach. UK: John Wiley \& Sons, Ltd.

Haque, N. U., \& Mirakhor, A. (1986). Optimal profit-sharing contracts and investment in an interest-free Islamic economy. International Monetary Fund Working Paper, WP/86/12.

Harden, A., Garcia, J., Oliver, S., Rees, R., Shepherd, J., Brunton, G., \& Oakley, A. (2004). Applying systematic review methods to studies of people's views: an example from public health. Journal of Epidemiology in Community Health, 58, 794-800.

Hasan, Z. (2002). Mudaraba as a mode of Inance in Islamic banking: Theory, practice and problems. The Middle East business and economic review, 14(2), 41-53.

Hassan, M. K., \& Kayed, R. N. (2009). The global financial crisis, risk management and social justice in Islamic fInance. ISRA International Journal of Islamic Finance, 1(1), 33-58.

Hearn, B., Piesse, J., \& Strange, R. (2012). Islamic Ønance and market segmentation: Implications for 
the cost of capital. International Business Review, 21, 102-113.

Huda, A. N. (2012). The development of islamic financing scheme for SMEs in a developing country: The Indonesian case. Procedia-Social and Behavioral Sciences, 52, 179-186.

Iqbal, M., Ahmad, A., \& Khan, T. (1998). challanges facing Islamic banking (Vol. 1): Islamic Research and training institute.

Iqbal, M., \& Llewellyn, D. T. (2002a). Introduction. In M. Iqbal \& D. T. Llewellyn (Eds.), Islamic Banking and Finance: New perspectives on profit-sharing and risk. Cheltenham, UK. Northampton, MA, USA: Edward Elgar.

Iqbal, M., \& Molyneux, P. (2005). Thirty years of Islamic banking: History, performance and prospects. New York: Palgrave Macmillan.

Iqbal, Z. (1997). Islamic Financial Systems. Finance EO Development, June, 42-45.

Iqbal, Z., \& Mirakhor, A. (2011). An introduction to Islamic finance: Theory and practice (2nd ed.). Singapore: John Wiley \& Sons (Asia) Pte. Ltd.

ISRA. (2011). Islamic Financial System: Principles $\mathcal{E}$ Operations. Kuala Lumpur: International Shari'ah Research Academy for Islamic Finance (ISRA).

Jaffar, M. M. (2010, December 5 - 7). Mudharabah and musyarakah models of joint venture investments between two parties. Paper presented at the International Conference on Science and Social Research (CSSR 2010), Kuala Lumpur, Malaysia.

Jouaber, K., \& Mehri, M. (2012). A Theory of Profit Sharing Ratio Under Adverse Selection: The Case of Islamic Venture Capital. Paper presented at the 29th International Conference of the French Finance Association (AFFI).

Kahneman, D. (1992). Reference points, anchors, norms, and mixed feelings. Organizational Behavior and Human Decision Processes, 51, 960312.

Karim, A. A. (2002). Incentive-compatible constraints for Islamic banking: Some lessons from Bank Muamalat. In M. Iqbal \& D. T. Llewellyn (Eds.), Islamic Banking and Finance: New perspectives on profit-sharing and risk (pp. 95-108). Cheltenham, UK. Northampton, MA, USA: Edward Elgar.

Kayed, R. N. (2012). The entrepreneurial role of profit-and-loss sharing modes of finance: theory and practice. International Journal of Islamic and Middle Eastern Finance and Management, 5(3), 203 - 228.

Khalil, A. F. A. A., Rickwood, C., \& Murinde, V. (2002). Evidence on agency-contractual problems in mudarabah financing operations by Islamic banks. In M. Iqbal \& D. T. Llewellyn (Eds.), Islamic Banking and Finance: New perspectives on profit-sharing and risk (pp. 57-92). Cheltenham, UK. Northampton, MA, USA: Edward Elgar.

Khan, F. (2010). How 'Islamic' is Islamic banking? Journal of Economic Behavior E Organization, 76, 805-820. 
Khan, M. (2011). Islamic banking practices: Islamic law and prohibition of Riba. Islamic Studies, 50(3/4), 413-422.

Khan, M. M., \& Bhatti, M. I. (2008). Developments in Islamic banking: The case of Pakistan. Hampshire, New York: Palgrave Macmillan.

Khan, T. (1995). Demand for and supply of PLS and mark-up funds of Islamic banks: Some alternative explanations. Islamic Economic Studies, 3(1).

Khan, T., \& Ahmed, H. (2001). Risk management: An analysis of issues in Islamic financial industry. Jeddah: Islamic Research and Training Institute-Islamic Development Bank.

Khan, T., \& BenDjilali, B. (2003). Modeling an exit strategy for Islamic venture capital finance. International Journal of Islamic Financial Services, 4(2), 1-10.

Khan, W. M. (1989). Towards an interest-free Islamic economic system. Journal of King Abdulaziz University: Islamic Economics, 1, 3-38.

Knoben, J., \& Oerlemans, L. A. G. (2006). Proximity and inter-organizational collaboration: A literature review. International Journal of Management Reviews, 8(2), 71-89.

Kuran, T. (1995). Further reflections on the behavioral norms of Islamic economics Journal of Economic Behavior and Organization, 27, 159-163

Kuran, T. (2004). Islam $\mathcal{E}$ Mammon: The Economic Predicaments of Islamism. Princeton, New Jersey: Princeton University Press.

Lewis, M. K. (2008). In what ways does Islamic banking differ from conventional finance? Journal of Islamic Economics, Banking and Finance, 4(3).

Mansoori, M. T. (2011). Is "Islamic Banking” Islamic? Analysis of current debate on Shari'ah legitimacy of Islamic banking and finance. Islamic Studies, 50(3/4), 383-411.

Mansour, W., Abdelhamid, M. B., \& Heshmati, A. (2015). Recursive profit-and-loss sharing. Journal of Risk, 17(6), 21-50.

Marizah, M., \& Nazam, D. (2016). Islamic corporate financing: Does it promote profit and loss sharing? Business Ethics: A European Review, 25(4), 482-497.

Marston, C., \& King, E. (2006). Factors that shape young people's sexual behaviour: A systematic review. The Lancet, 368, 1581-1586.

Mills, P. S., \& Presley, J. R. (1999). Islamic finance: Theory and practice USA: Palgrave Macmillan.

Mirakhor, A., \& Zaidi, I. (2007). Profit-and-loss sharing contracts in Islamic finance. In K. Hassan \& M. Lewis (Eds.), Handbook of Islamic Banking (pp. 49-63): Edward Elgar Publishing.

Mishkin, F. S. (1995). The economics of money, banking, and financial markets (4 ed.). New York: Harper Collins College Publications. 
Mishkin, F. S., \& Eakins, S. G. (2011). Financial markets and institutions (7 ed.): Prentice Hall.

Nagaoka, S. (2010). Reconsidering mudarabah contracts in Islamic finance: What is the economic wisdom (hikmah) of partnership-based instruments? Review of Islamic Economics, 13(2), 65-79.

Nienhaus, V. (1983). Profitability of Islamic PLS banks competing with interest banks: Problems and prospects. Journal of Research in Islamic economics, 1(1), 37-47.

Nouman, M., \& Ullah, K. (2014). Constraints in the application of partnerships in Islamic banks: The present contributions and future directions. Business and Economic Reivew, 6(2).

Nouman, M., \& Ullah, K. (2016). New perspectives on partnership contracts in Islamic banks. Paper presented at the 1st CEIF International Conference on Towards Financial Inclusion: Developments in Islamic Economics, Banking and Finance, Peshawar, Pakistan.

Othman, A. N., \& Masih, M. (2015). Do profit and loss sharing (PLS) deposits also affect PLS financing? Evidence from Malaysia based on DOLS, FMOLS and system GMM techniques. Munich Personal RePEc Archive. (MPRA Paper No. 65224). from MPRA http://mpra.ub.uni-muenchen.de/65224/

Paterson, B. L. (2012). It looks great but how do I know if it Its?: An introduction to meta-synthesis research. In K. Hannes \& C. Lockwood (Eds.), Synthesizing qualitative research: Choosing the right approach. UK: John Wiley \& Sons, Ltd.

Petticrew, M. (2001). Systematic reviews from astronomy to zoology: myths and misconceptions. British Medical Journal, 322(13), 98-101.

Petticrew, M. A., \& Roberts, H. (2006). Systematic reviews in the social sciences. Oxford: Blackwell.

Pittaway, L., Robertson, M., Munir, K., Denyer, D., \& Neely, A. (2004). Networking and innovation: a systematic review of the evidence. International Journal of Management Reviews, 5/6(3\&4), 137-168.

Pryor, F. L. (1985). A guidebook to the comparative study of economic systems: Prentice Hall.

Pryor, F. L. (2007). The Economic Impact of Islam on Developing Countries. World Development, 35(11), 1815-1835.

Rethel, L. (2011). Whose legitimacy? Islamic finance and the global financial order. Review of International Political Economy, 18(1), 75-98.

Roy, D. A. (1991). Islamic Banking. Middle Eastern Studies, 27(3), 427-456.

Sadique, M. A. (2010a). Islamic banks' dilemma between ideals and practice: Debt or equity Global Journal of Management and Business Research, 10(2).

Sadique, M. A. (2010b). Transition of Islamic banks from debt-based modes to equity-based financing: issues and prospects. Paper presented at the International Conference on Islamic Banking \& Finance: Cross Border Practices \& Litigations, International Islamic University Malaysia.

Sadique, M. A. (2012). Capital and profit sharing in Islamic equity financing: Issues and prospects. Kuala 
Lumpur: The Other Press.

Sadr, K. (1999). The Role of Musharakah Financing in the Agricultural Bank of Iran Arab Law Quarterly, 14(3), 245-256.

Sadr, K., \& Iqbal, Z. (2002). Choice between debt and equity contracts and asymmetrical information: Some empirical evidence. In M. Iqbal \& D. T. Llewellyn (Eds.), Islamic Banking and Finance: New perspectives on profit-sharing and risk (pp. 139-154). Cheltenham, UK. Northampton, MA, USA: Edward Elgar.

Samad, A., Gardner, N. D., \& Cook, B. J. (2005). Islamic banking and finance in theory and practice: The experience of Malaysia and Bahrain. The American Journal of Islamic Social Sciences, 22(2), 69-86.

Sarker, M. A. A. (1999). Islamic business contracts, agency problem and the theory of the Islamic firm. International Journal of Islamic Financial Services, 1(2).

Shahid, A., Shagufta, Ahmad, N., Ahmad, H., \& Shafique, M. N. (2015). An exploratory study of SHARI'AH compliance in Islamic banking: Evidences from Bangladesh Arabian Journal of Business and Management Review (Nigerian Chapter), 3(9).

Shaikh, M. A. (2011). Contemporary Islamic banking: The issue of Murlbahah. Islamic Studies, 50(3/4 ), 435-448.

Sherwood, G. (1999). Meta-synthesis: Merging qualitative studies to develop nursing knowledge. International Journal of Human Caring, 3, 37-42.

Shinsuke, N. (2012). Critical Overview of the History of Islamic Economics: Formation, Transformation, and New Horizons. Asian and African Area Studies, 11(2), 114-136.

Siddiqi, M. N. (1983). Issues in Islamic banking. Leicester, U.K.: The Islamic Foundation.

Siddiqi, M. N. (1985). Partnership and profit-sharing in Islamic law. Leicester, U.K.: The Islamic Foundation.

Siddiqi, M. N. (1991). Some economic aspects of mudarabah: Review of Islamic economics. Journal of the International Association for Islamic Economics, 1(2), 21-34.

Siddiqi, M. N. (2006). Islamic banking and finance in theory and practice: A survey of state of the art Islamic Economic Studies, 13(2).

Simon, H. A. (1945). Administrative behavior (3 ed.). New York: Free Press.

Song, M. I., \& Oosthuizen, C. (2014). Islamic banking regulation and supervision: Survey results and challenges. International Monetary Fund.

Sugema, I., Bakhtiar, T., \& Effendi, J. (2010). Interest versus profit-loss sharing credit contract: Effciency and welfare implications. International Research Journal of Finance and Economics, 45, 58-67.

Sumarti, N., Fitriyani, V., \& Damayanti, M. (2014). A mathematical model of the profit-loss sharing (PLS) scheme Procedia - Social and Behavioral Sciences, 115, 131 - 137. 
Sundararajan, V., \& Errico, L. (2002). Islamic financial institutions and products in the global financial system: Key issues in risk management and challenges ahead. International Monetary Fund Working Paper Working Paper, WP/02/192.

Thomas, J., Kavanagh, J., Tucker, H., Burchett, H., Tripney, J., \& Oakley, A. (2007). Accidental injury, risk-taking behaviour and the social circumstances in which young people live: a systematic review. University of London, London: EPPI-Centre, Social Science Research Unit, Institute of Education.

Thomas, J., Sutcliffe, K., Harden, A., Oakley, A., Oliver, S., Rees, R., . . Kavanagh, J. (2003). Children and healthy eating: a systematic review of barriers and facilitators. University of London, London: EPPI-Centre, Social Science Research Unit, Institute of Education.

Tranfield, D., Denyer, D., \& Smart, P. (2003). Towards a Methodology for Developing Evidence-Informed Management Knowledge by Means of Systematic Review. British Journal of Management, 14(3), 207-222.

Tversky, A., \& Kahneman, D. (1981). The framing of decisions and the psychology of choice. Science, 211, $453 \llbracket 458$.

Usmani, M. T. (2002). An introduction to Islamic finance. The Hague: Kluwer Law International.

Usmani, M. T. (2007). An introduction to Islamic finance. Karachi, Pakistan: Maktaba Ma'ariful Qur'an.

Vahed, G., \& Vawda, S. (2008). The viability of Islamic banking and finance in a capitalist economy: A South African case study. Journal of Muslim Minority Affairs, 28(3), 453-472.

Vogel, F. E., \& Hayes, S. L. (1998). Islamic law and finance: Religion, risk and return. The Hague: Kluwer Law International.

Warde, I. (1999). The revitalization of Islamic profit-and-loss sharing. Paper presented at the Third Harvard University Forum on Islamic Finance: Local Challenges, Global Opportunities Cambridge, Massachusetts.

Warde, I. (2000). Islamic finance in the global economy. Edinburgh: Edinburgh University Press.

Williamson, O. E. (1981). The economics of organization: the transaction cost approach. The American Journal of Sociology, 87(3), 548-577.

Williamson, O. E. (1985). The economic institutions of capitalism (3 ed.). New York: Free Press.

Williamson, O. E. (1993). Opportunism and its critics. Managerial and Decision Economics, 14, 97-107.

Wilson, R. (2003). Regulatory challenges posed by Islamic capital market products and services. University of Durham, UK: IOSCO task force on Islamic capital market. Centre for Middle Eastern and Islamic Studies.

World Finance. (2018). Islamic Finance Awards 2018. Retrieved January, 2018, from https://www. worldfinance.com/awards/world-finance-islamic-finance-awards-2018 
Yasseri, A. (2002). Islamic banking contracts as enforced in Iran. In M. Iqbal \& D. T. Llewellyn (Eds.), Islamic Banking and Finance: New perspectives on profit-sharing and risk (pp. 155-167). Cheltenham, UK. Northampton, MA, USA: Edward Elgar.

Yousef, T. M. (2004). The murabaha syndrome in Islamic finance: Laws, institutions and politics. In C. Henry \& R. Wilson (Eds.), The politics of Islamic finance. Edinburgh: Edinburgh University Press.

Yousefi, M., McCormick, K., \& Abizadeh, S. (1995). Islamic banking and Friedman's rule. Review of Social Economy, 53(1), 65-87.

Zaher, T. S., \& Hassan, M. K. (2001). A comparative literature survey of Islamic finance and banking. Financial Markets, Institutions $\mathcal{E}$ Instruments, 10(4), 155-199.

Zandi, G., Ariffin, N. M., \& Shahabi, A. (2012). Some issues on Murabahah practices in Iran and Malaysian Islamic banks. African Journal of Business Management, 6(24), 7066-7073.

Zhou, X., \& Wu, Y. (2011). Sharing losses and sharing gains: Increased demand for fairness under adversity. Journal of Experimental Social Psychology, 47, 582-588.

Zimmer, L. (2006). Qualitative meta-synthesis: a question of dialoguing with texts. Journal of Advanced Nursing, 53, 311-318. 